\title{
Implied Volatility Forecasting in the Options Market: A Survey
}

\author{
Najmi Ismail Murad Samsudin , Azhar Mohamad* \\ Department of Finance, KENMS, International Islamic University Malaysia, 53100 Kuala Lumpur, Malaysia
}

*Corresponding author:dr@azharmohamad.asia; m.azhar@iium.edu.my

\begin{abstract}
Implied volatility is regarded as one of the most important variables for determining profitability in options trading. Implied volatility gives indication about the future volatility of the underlying asset and can be used to predict the degree to which the asset price might swing and thus whether the options could become profitable before expiration. Volatility forecasting can be grouped into two main categories namely option-implied volatility and historical time-series models. There is an academic debate as to which of the two methods has stronger predictive power. In this paper, we provide a review of options-implied volatility forecasting studies. This survey of the literature suggests there is no consensus to indicate that the implied volatility has stronger predictive power than historical time series in forecasting realized volatility.
\end{abstract}

Keywords: Implied volatility; historical volatility; options; forecasting; literature review

\begin{abstract}
Abstrak
Volatiliti implisit dianggap sebagai salah satu pembolehubah yang paling penting untuk menentukan keuntungan dalam perdagangan opsyen. Volatiliti implisit memberikan gambaran tentang turun naik harga pasaran aset sandaran masa depan. Ia juga boleh digunakan untuk meramalkan sejauh mana harga aset mungkin berubah, justeru itu ia memberi maklumat mengenai opsyen yang boleh memberi keuntungan sebelum tamat tempoh hayatnya. Ramalan volatiliti boleh dikategorikan ke dalam dua kumpulan utama iaitu volatiliti implisit-opsyen dan volatiliti dari model siri masa. Terdapat perdebatan akademik antara kedua-dua kaedah ramalan tersebut, yang manakah mempunyai kuasa ramalan kuat. Dalam kertas ini, kami menyediakan survei mengenai kajian volatiliti implisit-opsyen. Tinjauan litratur mencadangkan tidak ada kata sepakat untuk menunjukkan bahawa volatiliti implisit mempunyai kuasa ramalan lebih baik berbanding volatiliti dari model siri masa untuk menentukan volatiliti semasa.
\end{abstract}

Kata Kunci: Volatiliti implisit; volatiliti dari model siri masa; opsyen, ramalan, tinjauan litratur.

(C) 2016 Penerbit UTM Press. All rights reserved

\subsection{INTRODUCTION}

Volatility has been one of the main topics of discussion in finance over the years, and volatility forecasting is the main building block in finance research on topics such as option pricing, portfolio selection, and risk management. However, it is extremely difficult to predict volatility accurately. Volatility is basically the rate of change of a certain financial product's price, irrespective of the direction of the movement. A trader needs to understand or have an idea of how the price of a financial product will change and the volatility can assist him or her to forecast movements in the prices of any financial product. In terms of options, the most practical aspect of volatility is related to options strategies and prices, where it creates the opportunity for the trader to determine relative valuations of options. Knowing which options are cheap or expensive, the trader knows when to buy or sell them.

Volatility forecasting can be broadly classified into two categories, namely option-implied volatility and historical time-series models, such as historical volatility, autoregressive conditional heteroscedasticity (ARCH), and stochastic models. The historical time-series volatility forecast is a mathematical expression of the magnitude of past price variations for a financial product, be they daily, weekly, monthly or yearly variations. This form of volatility is simply based on historical observation and does not reflect expectations of future price volatility. It gives the trader an indication of how much the price might move in the future based on past trends rather than a prediction of the future trend. A high historical volatility may suggest that the price of the financial product has been going up and down rapidly over a period of time but has not actually moved significantly from its original price. Likewise, a low historical volatility may mean that the financial product's price has not been moving much but has been moving steadily in one direction.

On the other hand, the option-implied volatility is regularly used by option traders due to its straightforwardness; most of the parameters need to be calculated, but the option-implied volatility is easily available. Bacha (2012) stated that the two most common uses of the optionimplied volatility were the following: (1) traders can use it to ascertain the value of an option and compare it with another and (2) it can be used to determine option mispricing, through the evaluation of the implied volatility against the actual or historical volatility; if the implied volatility is higher than the historical volatility, then the option is overvalued or overpriced and vice versa. Furthermore, the option-implied volatility for an option contract represents the forecast of the future average volatility of the underlying asset over the remaining life of the option contract (Hull and White, 1987). 
In order to obtain the option-implied volatility, one must first solve the Black-Scholes (1973) option pricing model. The model has five parameters, which are (1) the stock price, (2) the exercise price of the option, (3) the time to maturity, (4) the interest rate, and (5) the volatility of the underlying asset. The first four parameters are observable and retrievable directly from the market but the volatility, which is the main item in the valuation, is not. The implied volatility is forward looking because it is an estimation of the future volatility of the underlying asset. In addition it gives an indication of how much the price of the underlying asset will move in the future.

The implied volatility is also said to be the investor fear gauge, according to studies by Whaley (2000) and Shaikh and Padhi (2014) relating to the volatility index (VIX) of the Chicago Board of Option Exchange (CBOE) and India VIX. These studies indicate that, during a period of high volatility, the prices of the underlying assets fall as the volatile market creates nervousness among the market participants. Investors thus require higher rates of return on their stocks, which in turn lead to falling stock prices.

The second common use of implied volatility is that of evaluating option mispricing when valuing options using the Black-Scholes (1973) option pricing model that incorporates the historical volatilities into the option price. Earlier studies have provided evidence of the mispricing of options using option valuation models such as the Black-Scholes. The theoretical price has recorded overpricing for out-ofthe-money options and underpricing for in-the-money options when compared to the market price in countries such as the US (Macbeth and Merville, 1979), Thailand (Shastri and Sirodom, 1995) and China (Powers and Xiao, 2014).

Harvey and Whaley (1992) stated that studies on implied volatility pertaining to option pricing have focused on three aspects, which are (1) how well the implied volatility predicts future volatility (Latane and Rendleman, 1976), (2) the dynamic linkages between changes in implied market volatility and changes in microeconomic variables (Schmalensee and Trippi, 1978) or the implied volatilities of individual stock options, and (3) changes in implied market volatility as a measure of abnormal activity in the marketplace (Day and Lewis, 1988). This study intends to look into the ability of implied volatility to forecast future volatility.

The results obtained from previous studies, including a number of empirical studies, regarding informational efficiency imply that the option-implied volatility can be a predictor of the future volatility. In addition, a pioneering study used cross-sectional data to examine 24 stock options from the CBOE using weekly data for a period of less than a year to examine the predictive ability of implied volatility, and the results showed a positive correlation between implied volatility and realized volatility (Latane and Rendleman, 1976), while other studies have used larger samples and longer periods of time (Chiras and Manaster, 1978; Beckers, 1981).

Moreover, some more recent studies have used time-series data for exchange rate futures options (Xu and Taylor, 1995), and Daily Eurodollar futures and futures options (Amin and $\mathrm{Ng}, 1997$ ). In addition, the implied volatility has been shown to outperform past volatility in forecasting future volatility for monthly expiries of S\&P 100 OEX (Christensen and Prabhala, 1998), the German DAX stock index and the DAX volatility index (Bluhm and Yu, 2001), and the Nifty index option from 2006 to 2011 (Singh, 2013).

Several studies have found that the option-implied volatility fails to predict future volatility, due to its inability to impound all the information available in the past returns. Those works used as the assets under study the weekly S\&P 100 OEX (Day and Lewis, 1992; Canina and Figlewski, 1993), and the S\&P CNX Nifty index (Dixit, Yadav and Jain, 2010). The empirical studies on option-implied volatilities have not only focused on the equity market, but also on other options, such as crude oil (Day and Lewis, 1993), foreign currency futures options (Jorion, 1996), and 35 futures options markets from 8 separate exchanges (Szakmary, Ors, Kim and Davidson, 2003). For a majority of the commodities studied, the option-implied volatility has been found to outperform the historical volatility as a predictor of future realized volatility.

Over the years, the research focus has shifted from studying the informational content of option-implied volatilities to comparing volatility forecasting based on option-implied volatilities with that based on (1) historical volatilities, such as the exponentially weighted moving average (EWMA), autoregressivemoving average (ARMA) and autoregressive integrated (ARIMA), (2) the ARCH family of models, for instance Generalized ARCH, Threshold GARCH, and IGARCH, and (3) stochastic volatility models, such as quasi-maximum likelihood estimation, and the generalized method of moments, to name a few (Lamoureux and Lastrapes, 1993; Jorion, 1996; Guo, 1996; Fleming, 1998). The finding has been that the option-implied volatility has some predictive power, and more than the historical volatilities. It has also been suggested that the best forecasts have come from the option-implied volatility due to the fact that such forecasts have been based on larger and timelier data sets (Poon and Granger, 2005).

One challenge of financial markets is that of correctly forecasting the daily volatility of financial assets in order to obtain a reasonable and fair price for derivatives securities. In Black-Scholes option pricing model, the implied volatility is deemed as an unbiased and efficient forecast of realized volatility. Hence, implied volatility ought to incorporate the information contained in all the other variables in the market information set in explaining future volatility. Thus, it is hypothesized that the implied volatilities impound all the information contained in the historical returns. Therefore, in an informationally efficient options market, forecasts based on implied volatilities should outperform forecasts based on historical returns. Some studies however reject the above opinion, claiming that the implied volatilities cannot impound all the information available in the past returns and cannot therefore provide a good forecast of future volatility. This leads to the notion that the options market is informationally inefficient.

\subsection{SURVEY OF THE LITERATURE}

\section{Theoretical Papers}

Derivatives securities are financial instruments whose value depends on the value of their underlying traded assets. The underlying assets are normally traded in the spot market, where buying and selling is done in cash and there is immediate delivery of the underlying assets. The price of the derivatives securities is determined today, but delivery happens in the future. The most common derivatives securities are forward contracts, future contracts, options, and swaps. This study focuses on call warrants as the warrants are also considered as options. An option is defined as the right, but not the obligation, by the option holder to buy or sell the underlying asset at a predetermined price within a stipulated time. Options can be divided into two types, namely, the call option that gives the holder the option to buy the underlying asset, and the put option that gives him/her the option to sell. Options can also be distinguished by when the holder of the option is allowed to convert his/her right. If the option can be exercised at any time prior to its maturity date, then the option is called American style, whilst if it can only be exercised at its maturity date it is termed a European-style option. 
The option moneyness is measured by the ratio of the spot price of the underlying asset to the exercise price of the option. It can be categorized into three types. For a call options these are as follows (for a put option, the reverse are true): (1) at-the-money means that the spot price is the same as the exercise price, (2) in-the-money means that the spot price is more than the exercise price, and (3) out-of-the-money means that the spot price is less than the exercise price. The seminal paper by Black and Scholes (1973) provided a significant contribution on the valuation of options, where they developed a model with five parameters, namely, (1) the stock price (S), (2) the exercise price or strike price $(\mathrm{K}),(3)$ the maturity date of the option $(\mathrm{T}),(4)$ the risk-free rate $(\mathrm{r})$, and $(5)$ the volatility $(\sigma)$ :

$$
\begin{gathered}
C=S \cdot N\left(d_{1}\right)-K e^{-r t} \cdot N\left(d_{2}\right) \\
P=K e^{-r t} \cdot N\left(-d_{2}\right)-S \cdot N\left(-d_{1}\right) \\
d_{1}=\frac{\ln \left(\frac{S}{K}\right)+\left[r+\left(\frac{\sigma^{2}}{2}\right)\right] T}{\sigma \sqrt{T}} \\
d_{2}=d_{1}-\sigma \sqrt{T}
\end{gathered}
$$

The model depends on several assumptions: (1) the risk-free interest rate remains constant during the life of the option, (2) the underlying asset return is log normally distributed and its volatility is constant throughout the life of the option, (3) the underlying asset gives no dividend, (4) the options are European style as they can only be converted into the underlying asset at maturity, (5) there are no transaction costs involved in buying or selling the underlying asset or the option, (6) there is no riskless arbitrage opportunity, and (7) the short selling of securities is permitted.

Assumption (3) states that the underlying asset provides no dividend but some stocks do give substantial dividends; hence, this will have a significant effect on the valuation of an option. Moreover, Merton (1973) stated that the value of an option would be affected by a change in the payout policy of a firm, whereby the value of the option would decline if the total payout to shareholders were to increase. Thus, Merton relaxed the assumption of no dividends in Black and Scholes (1973) by allowing a constant continuous dividend yield on the underlying asset. An additional parameter is introduced; q represents the annualized continuously compounded dividend yield during the remaining life of the option. The new formulae are

$$
\begin{gathered}
C=\mathrm{S}_{\mathrm{t}} \mathrm{e}^{-\mathrm{qt}} \cdot N\left(d_{1}\right)-K_{t} e^{-r t} \cdot N\left(d_{2}\right) \\
P=K_{t} e^{-r t} \cdot N\left(-d_{2}\right)-S_{t} \mathrm{e}^{-\mathrm{qt}} \cdot N\left(-d_{1}\right) \\
d_{1}=\frac{\left[\ln \left(\frac{S}{K}\right)+\left(r_{t}-q_{t}\right) T+\left[r+\left(\frac{\sigma^{2}}{2}\right)\right]\right.}{\sigma \sqrt{T}} \\
d_{2}=d_{1}-\sigma \sqrt{T}
\end{gathered}
$$

Working from the same procedure and assumptions that Black and Scholes (1973) used for an option, Black (1976) then derived a formula for the value of a commodity option. The basis for valuing the commodity option is similar to that for the option that pays a continuous dividend at a rate that is equal to the stock price multiplied by the interest rate. The option is a European option as it can be exercised only at maturity. The resulting formulae are

$$
\begin{gathered}
C=S e^{\mathrm{r}(\mathrm{t}-t *)} \cdot N\left(d_{1}\right)-c^{*} \cdot N\left(d_{2}\right) \\
P=\mathrm{c}^{*} \cdot N\left(-d_{2}\right)-S e^{\mathrm{r}(\mathrm{t}-t *)} \cdot N\left(-d_{1}\right) \\
d_{1}=\frac{\left[\ln \left(\frac{S}{c^{*}}\right)+\left(\frac{\sigma^{2}}{2}\right)\left(t^{*}-t\right)\right]}{\sigma \sqrt{\left(t^{*}-t\right)}} \\
d_{1}=\frac{\left[\ln \left(\frac{S}{c^{*}}\right)-\left(\frac{\sigma^{2}}{2}\right)\left(t^{*}-t\right)\right]}{\sigma \sqrt{\left(t^{*}-t\right)}}
\end{gathered}
$$

The parameter $t$ representing the time, while $t^{*}$ is the time at which the transaction will occur. $c^{*}$ is the exercise price of the option, and the other parameters are similar to those in Black and Scholes (1973).

Another assumption of the model developed by Black and Scholes (1973) is that the volatility of the underlying asset is constant throughout the life of the option (assumption 2), a condition that will not hold for every underlying asset. Fama (1965) found that the stock 
return should not be constant because the stock price is leptokurtic, with the historical values clustered such that small changes happen infrequently. Nevertheless, this also means that large fluctuations are more likely to occur within the fat tails. The other type of volatility is stochastic volatility, under which the variance of the underlying asset changes in an uncertain way rather than remaining constant. Some of the best-known stochastic volatility models are the ARCH family of models. These models formulate conditional variance of the return via a maximum likelihood procedure rather than using the normal sample standard deviations. The ARCH processes introduced by Engle (1982) had zero mean, as they were serially uncorrelated with non-constant variances conditional on the past. For such processes, the recent past provides information pertaining to the one-period forecast.

Meanwhile, the issue with ARCH model applications is the introduction of an arbitrary linear declining lag structure in the conditional variance equation to take account of the long memory a condition where the effects of volatility shocks decay slowly which is often detected by the autocorrelation of measures of volatility, such as absolute or squared returns which is typically found in empirical work. The estimation of a totally free lag distribution often leads to violation of the non-negativity constraints. Therefore, Bollerslev (1986) introduced the Generalized ARCH (GARCH) model to allow for a more flexible lag structure, as it permits a more parsimonious description in many situations. The ARCH and GARCH models capture volatility clustering and leptokurtosis. Nevertheless, since their distributions are symmetric, they fail to model the leverage effect. In order to address this asymmetry of return volatility problem, asymmetric extensions of GARCH have been proposed, such as the Exponential GARCH (EGARCH) proposed by Nelson (1991), the so-called Glosten, Jagannathan, and Runkle GARCH (GJR GARCH) proposed by Glosten et al. (1993), and the threshold GARCH (TGARCH) model proposed by Zakoian (1994).

\section{Empirical Papers}

\section{Studies in the US}

The earliest study investigating the relationship between implied volatility and realized volatility, by Latane and Rendleman (1976), used cross-sectional data, namely the closing prices of options from 24 companies and stocks listed on the CBOE for a period of 38 weeks from October 1973 to June 1974. The authors calculated the implied standard deviation (ISD) or implied volatility by numerically solving the Black-Scholes model. In order to get a single estimate of the standard deviation for each option, weights were given to options with different strike prices and maturities. The weighted average ISD was then calculated for each company. Next, three other standard deviations were computed to represent the actual return variability using the monthly log price return calculated over a four-year period that ended in September 1973, which can be thought of as the historical volatility. The realized volatility was calculated as (1) the weekly log price return for the 38-week period adjusted to a monthly basis, and (2) the monthly log price return over a two-year period that ended in March 1974. The study also found that the highest correlation was between the weighted averages implied standard deviation and actual standard deviation over various time periods as compared to the other two standard deviation based on historical weekly and monthly log price returns. Hence, they concluded that the period for which the weighted average implied volatility was employed, provided a better estimation of future return variability than did the standard deviation calculated from historical data.

A study by Chiras and Manaster (1978) - which employed all stock options from the CBOE and used monthly data from June 1973 to April 1975 - argued that the weighted average ISD calculated by Latane and Rendleman (1976) was not a true weighted average because the sum of the weights was less than one. They used the dividend-adjusted Black-Scholes model, as proposed by Merton (1973), to calculate the ISD for each stock. They concluded that the weighted ISD was a substantially better predictor of the standard deviation (realized volatility) in the last 14 months of the study period than was the historical standard deviation (historical volatility).

The subsequent research by Beckers (1981) examined the predictability of ISD by taking into account the problems of dividends and the optimal weighting scheme. The study used daily closing prices for 62 to 115 stock options listed on the CBOE, and segmented them into ten time intervals between April 1975 and July 1977 in order to avoid overlaps in the observation period. In addition, a five-day arithmetic mean was used in order to eliminate estimation error that might arise for any single day. The author concluded that at-the-money options provided more relevant information than either in-the-money or out-of-the-money options.

Another study focused on ten individual stock options on the CBOE. Lamoureux and Lastrapes (1993) examined the orthogonality of at-the-money call options by comparing the behavior of measured variances from the options market and the underlying stock market. They compared the historical volatility estimates with the GARCH model volatility forecast and concluded that implied volatility contained useful information for forecasting volatility. Their results were consistent with those of Day and Lewis (1992); see below for a description of the latter study.

The earlier studies focused on individual stocks and stock options, gathering data from different markets. However, later studies shifted their attention towards index options, for which data on the underlying assets and the option could be obtained from the same market. Harvey and Whaley (1992) studied the dynamic behavior of the S\&P 100 index options implied volatility from October 1985 to July 1989. They stated that their study on market volatility was predictable in the statistical sense, and a trading simulation showed that there was no possibility of any arbitrage profit. This supported the notion that the S\&P 100 index options market was efficient.

In the study mentioned earlier, Day and Lewis (1992) investigated the information content of future estimates of the futures market volatility and, implicitly, in the prices of call options on the S\&P 100 index, using a time-series regression test. Their sample, from November 1983 to December 1989, produced results indicating that although implied volatility was biased, it containincremental information relative to the conditional volatility estimates from GARCH and EGARCH. However, the results obtained from the out-of-sample weekly forecast from November 1983 to December 1989 suggested that it was difficult to predict the weekly volatility.

In another piece of research, Canina and Figlewski (1993) used the daily closing prices of the S\&P 100 index call option from March 15, 1983 to March 28, 1987, which was prior to the crash, to test whether the calculation of implied volatility from the standard fixedvolatility model was an efficient way to obtain a volatility forecast. They found that the implied volatility obtained from the S\&P 100 call option was an unbiased and efficient forecast, as it had no statistically significant correlation with the realized volatility. Furthermore, it did not incorporate information contained in the recently observed volatility. However, Christensen and Prabhala (1998) disputed the results obtained by Canina and Figlewski (1993), using the monthly S\&P 100 index option as their data sample to avoid overlapping of data. They also lengthened the data period, which ran from November 1983 to May 1995, to include the regime shift of the October $1987 \mathrm{crash}$. The 
conclusion they reached was that the implied volatility outperformed historical volatility in forecasting future volatility and that it contained the information of the historical volatility. This result complemented the outcomes obtained by Jorion (1995) and Harvey and Whaley (1992) on issues of errors-in-variables in the context of the S\&P 100 option.

Fleming (1998) utilized the general method of moments approach, introduced by Hansen (1982), to investigate whether the S\&P 100 index option-implied volatility provided a good forecast of future stock market volatility, and found that both the call and put option-implied volatilities were biased forecasts. However, they did contain relevant information regarding future volatility. In addition, the implied volatility ex-ante forecast dominated the historical volatility and its forecast error was orthogonal to parameters frequently linked to conditional volatility.

Blair et al. (2001), meanwhile, investigated the incremental information in high-frequency S\&P 100 returns. They concluded that the in-sample analysis of S\&P 100 daily returns using low-frequency data and ARCH models offered no evidence of incremental information in daily index returns beyond that provided by the VIX index of implied volatilities. The data period covered January 2, 1987 to December 31 , 1992, and consisted of 1,519 observations. The results were in line with the conclusions drawn by Andersen and Bollerslev (1998) based on their study of foreign exchange volatility.

Christensen and Hansen (2002) extended the study of Christensen and Prabhala (1998) on the S\&P 100 OEX, covering the period from April 1993 to February 1997. They divided the implied volatility into call and put implied volatilities in order to identify any difference in their predictive power. Their contribution, they claimed, consisted of the method they used to calculate the implied volatility. Using Black (1976), they constructed a trade weighted average of individual implied volatilities for all call and put options. They confirmed the results obtained by Christensen and Prabhala (1998), and their OLS results showed the call implied volatility to be a better predictor than the put implied volatility.

In a recent study employing the S\&P 100 index, covering 1,725 trading days from January 6, 1997 to November 14, 2003, Koopman et al. (2005) included the realized volatility as an explanatory variable in assessing the forecasting capability of four classes of volatility models, namely, unobserved component, Autoregressive Fractionally Integrated Moving Average (ARFIMA), stochastic volatility, and GARCH.The ARFIMA realized volatility model provided the most accurate forecast and outperformed the implied volatility in forecasting the S\&P 100 index volatility.

Becker et al. (2006) moved away from the conventional way of measuring the implied volatility to a model-free estimate, by adopting Jiang and Tian's (2005) approach. They used the VIX, introduced by the CBOE on September 22, 2003 and published on their website.Put and call options were calculated using the S\&P 500 index as the underlying. Using daily data from January 1990 to October 2003 as the sample for their study, they found evidence that the VIX was an inefficient forecast, with the availability of other information improving VIX as a volatility forecast. The results from their study contradicted those of Jiang and Tian (2005), as they found evidence that the modelfree implied volatility was a better forecast of future volatility and that the information contained in the model-free implied volatility included the information from the Black-Scholes implied volatility and the past realized volatility. Jiang and Tian (2005) calculated their model-free implied volatility from Britten-Jones and Neuberger's (2000) diffusion assumption, with daily data from June 1988 to December 1994 for the S\&P 500, while Becker et al. (2006) retrieved the VIX directly from the CBOE and that may explain their contradicting findings.

A more recent study using the VIX was carried out by Bentes (2015) who examined the accuracy of implied volatility and GARCH forecast volatility for predicting the ex-post volatility. The study used monthly VIX data and data on the underlying indexes of Hong Kong, India, Korea and the US, from October 2003 to July 2012. The study found the GARCH forecast volatility to be a better predictor of realized volatility than the implied volatility. Another recent study by Seo and Kim (2015) found that, to improve the option-implied volatility forecast of future returns, the forecasting model needed to take into consideration investor sentiment. Their study used high-frequency data for the S\&P 500 index for the period from January 1996 to August 2010.

In another study, Shu and Zhang (2003) used S\&P 500 data from January 1995 to December 1999 to investigate the effects of measurement error in realized volatility and implied volatility on the stability of the relationship between the two volatilities. The results indicated that the forecast ability could be improved if a more accurate measurement of realized volatility was developed from five-minute intraday returns. The study also found that the implied volatility from the Black-Scholes model had more explanatory power than the implied volatility calculated based on Heston (1993), a stochastic volatility model where it allows the volatility to follow a random process where it can improves the option pricing model.Finally, all the information contained in the historical volatility was reflected by the implied volatility, proving the efficiency of the information embedded in the market process.

Other researchers to have studied S\&P 500 options include Ederington and Guan (2002a), who examined how well the implied volatility forecasted future stock market volatility in an active market that was a subject to less measurement error. It is a result where the implied volatility deviate from the true market volatility due to the bid-ask spread, non-synchronous price and minimum price increment. The S\&P 500 options market trades side-by-side with its underlying future, hence minimise the condition that can give rise to the measurement error.They found that the implied volatility had strong predictive power and subsumed the information in the historical volatility. Furthermore, the forecasting results were quite sensitive to the forecasting horizon. In a different paper, Ederington and Guan (2002b) compared the averages of implied volatilities used in Latane and Rendleman (1976), Beckers (1981), and Whaley (1982) papers, with the one used by the commercial vendors such as Bloomberg in the S\&P 500 option market. The found that most of the implied volatility averages provided better forecasts than the time-series and naïve models, but the differences between the averages were small. The study also indicated that the implied volatility was upward biased in its measurement of expected volatility; however, the bias became stable over time.

Furthermore, Ederington and Guan (2002c) examined the volatility smile caused by using the wrong pricing model to calculate the implied volatility. All the options, however, shared similar implied volatilities. They computed the implied volatility using Black's (1976) model and the evidence indicated that high-implied-volatility options were significantly overpriced in relation to low-implied-volatility options. This reflected the demand for out-of-the-money puts to hedge against the market that failed to push up the implied volatility on the low-strike options.

Meanwhile, a more recent study by Ederington and Guan (2005) used the daily settlement prices for the S\&P 500 futures and S\&P 500 futures options from January 1988 to March 2003 to examine how the information in implied volatilities differed according to moneyness. The findings indicated that the implied volatilities from out-of-the-money put options and in-the-money call options were biased and inefficient predictors of future volatility. In contrast, the implied volatilities from out-of-the-money call options and in-the-money put options 
were both biased and efficient. The results also showed that the most informative implied volatilities were those with the lowest smiles, or what the authors referred to as an information frown.

Jing and Gui (2015) examined the daily data for all S\&P 500 call options from January 2006 to January 2014 in investigating the predictive power of the model-free implied volatility and the GARCH model in forecasting the future volatility. They found the model-free implied volatility to be more effective for predicting the future realized volatility.

Likewise, a paper by Busch et al. (2011) used high-frequency data on the S\&P 500, the \$/DM exchange rate, and the 30-year T-bond to investigate the role of implied volatility in forecasting future realized volatility in relation to a continuous sample path and a jump. The empirical outcome showed that implied volatility included all the information of the continuous and jump components of realized volatility in all three markets. The forecasting evidence also indicated that the implied volatility was an unbiased forecast of the sum of the continuous and jump components. Thus, they concluded that the realized volatility and its components could be used for an ex-post assessment of what the volatility had been, whether there had been jumps in the price or not.

Scott and Tucker (1989) conducted a study on five foreign currency call options, namely, the British pound, the Canadian dollar, the Deutschmark, the Japanese yen, and the Swiss franc, which were traded on the Philadelphia stock exchange (PHLX) from March 1983 to March 1987. They investigated the accuracy of the forecasts provided by implied volatilities from the Black-Scholes model and the constantelasticity variance model, by extending the methodologies employed by Latane and Rendleman (1976) and Beckers (1981) to foreign exchange and foreign exchange options. They showed the forecast from the Black-Scholes model to be as accurate as that from the more complex constant-elasticity variance model.

Another study, by Xu and Taylor (1995), used four foreign currency options from the PHLX to examine the relative importance of implied and historical volatility as predictors, utilizing ARCH models. The results were obtained from daily-generated data, from January 1985 to January 1992. Among the four currency options, those for the British pound, the Deutschmark, and the Swiss franc offered the most favorable predictions of one-period-ahead conditional volatility and the implied volatility gave unbiased predictions of future volatility.

Jorion $(1995,1996)$ investigated the information content and predictive power of the volatility implied by options on foreign currencies traded on the Chicago Merchantile Exchange (CME), aiming to minimize the measurement error that had been found to arise in previous work on the informational content of implied standard deviation, which provided a biased forecast of future volatility (Canina and Figlewski, 1993). He used daily data for the period from January 1985 (DM), July 1986 (JY), or March 1985 (SF) until February 1992, for at-the-money options on the German Deutschmark, Japanese yen, and Swiss franc, the three currencies that had been the most active in the CME up until then. He found that implied standard deviation provided a biased volatility forecast but the ex-post forecast provided by the implied standard deviation outperformed the historical time-series model and the GARCH model.

Amin and Ng (1997) used the Eurodollar future in their study and concluded that the Heath-Jarrow-Morton (1992) implied volatility from Eurodollar options explained most of the realized interest rate volatility. The Eurodollar futures options carried very low transaction costs because the assets and options were traded in the same market, as compared to the OEX and the individual stock option, for which the transaction costs were high. This might have permitted the market price to deviate significantly from the theoretical price (Canina and Figlewski, 1993). Also, some corrections were made in this study relating to biases found in previous studies. In order to avoid model misspecification, they examined the implied volatility derived from five interest rate option models within the Heath-Jarrow-Morton framework for the pricing of Eurodollar futures options.

A more recent paper on the foreign currency options market was conducted by Kazantzis and Tessaromatis (2001) to investigate the volatility behavior of six foreign currencies, namely, the GB pound sterling, the Deutschmark, the Japanese yen, the Swiss franc, the Australian dollar, and the Canadian dollar, against the US dollar. The study showed that the implied volatility had a greater information content than the historical volatility. Furthermore, the implied volatility was found to provide better forecasts than the historic or GARCHbased volatility for periods ranging from one day to three months. In spite of this, the implied volatility produced biased estimates of the future realized volatility.

One of the most recent studies was by Pilbeam and Langeland (2014), who investigated the efficiency of foreign exchange rates between four currencies, the Euro, the pound, the Swiss franc, and the yen, and the dollar market in pricing option volatility, by pitting the forecasts obtained from the implied volatility against three different univariate GARCH models, namely, GARCH (1,1), EGARCH, and GRJ-GARCH. The daily data covered January 2002 to December 2011, subsequently divided into two periods, (1) 2002 to 2007, and (2) 2008 to 2011, differentiated by periods of low and high volatility respectively. The authors concluded that the three GARCH models were outperformed by implied volatility in forecasting future volatility, in periods of low and high volatility. However, the models performed significantly better in the period of low volatility.

Meanwhile, Szakmary et al. (2003) tested the predictive power of implied volatilities in comparison to historical volatilities and GARCH-based volatility estimates, using broader data from 35 futures options markets from 8 separate exchanges in Chicago, New York, London, and France. They found that the implied volatility from 34 out of the 35 futures options had predictive power superior to that of the historical volatility and GARCH models, in predicting the subsequent realized volatility. The findings from the study were similar to those of Christensen and Prabhala(1998) for equity indices, and of Jorion (1995) for currency futures options.

A recent study on the predictive power of exchange-traded funds carried out by Duan and Lin (2014) compared the abilities of GARCH and GJR-GARCH to that of the implied volatility from the NASDAQ 100 index. The results showed that the implied volatility had the best predictive power. In addition, if the implied volatility was added to the Garch and GJR-GARCH models, the ability to forecast future return volatility was enhanced. However, the authors noted that a shortcoming of the study was that they did not use current data, but daily data from March 2001 to June 2003, implying that the study was not robust.

\section{Studies Outside Of The US}

The pioneering study related to forecasting was conducted by Bluhm and Yu (2001)using daily data for the DAX index of the German stock market from January 1, 1988 to June 30, 1999 to compare volatility forecasting using univariate time-series techniques, such as the EWMA, the ARCH-based, and the Stochastic Volatility models, to the implied volatility derived from option prices. The results indicated that no single method could be considered the best, since the best performer would depend on the purpose. For option pricing, implied volatility and 
stochastic volatility would be best, while for Value-at-Risk, the ARCH-type model was more practical. The results were consistent with the findings of Blair et al. (2001) and Jorion (1995).

Filis (2009) analyzed the relationship between implied volatility and realized volatility in the Greek derivatives market using call and put option implied volatility. Daily data from January 2000 to January 2003, obtained from the Athens Derivatives Exchange and Athens Stock Exchange, were used to calculate the at-the-money call and put option implied volatilities. The results indicated that the implied volatility was a biased and inefficient predictor for the realized volatility, reflecting that the Greek derivatives market was inefficient.

A unique study in relation to the informational content of implied volatility was carried out by Viteva et al. (2014) using the carbon futures traded on the European Climate Exchange (ECX), for the period from January 2008 to December 2010. The ECX is the world's largest carbon derivatives exchange, on which carbon dioxide emissions are traded between companies that have installed climate-friendly technology and reduced their carbon emissions by more than is required and companies that exceed their emission limits. They found implied volatility to be highly informative about future volatility but a biased forecast of future volatility over the remaining life of the option. However, the forecast provided by the implied volatility was found to be statistically significant in predicting future volatility changes.

Another recent and distinct study came from Birkelund et al. (2015), who developed an implied volatility index for the Nordic power forwards market, an electricity-linked implied volatility index. They used high-frequency data (every 30 minutes) to develop their daily observations, with a sample period from October 2005 to September 2011. The results suggested that there was a risk premium in the option contract price and that the volatility index was a biased estimator of the future realized volatility. The authors claimed that their findings were similar to those of Ederington and Guan (2002b).

Frijins et al. (2010) developed an implied volatility index for the Australian (AVX) stock market, from January 2002 until December 2006, using the daily S\&P/ASX200 index option, and assessed its information content regarding stock market returns and future volatility. They observed that, for the stock market return, AVX had a negative and asymmetric contemporaneous relationship. This meant that the influence of an increase in the implied volatility on negative returns was greater than that of a decrease in the implied volatility when there was a positive return. For forecasting future volatility they found that the AVX improved the in-sample forecasting power of various GARCH specifications and that the AVX contained important information for the future volatility out-of-sample.

A study from Taiwan on market imperfection and the information content of implied volatility and realized volatility revealed that the implied volatility contained information on the future volatility. In relation to market imperfections, the authors found evidence that trading in options minimized the effects of market friction, such as short-sale restrictions and price limit rules, as imposed by the Taiwan Stock Exchange. Consequently, designing derivative products, such as the index option, eased the dilemma caused by market imperfections (Wong and Tu, 2009).

In a recent piece of research on the Korean capital market, Byun et al. (2011) used KOSPI 200 intraday data from July 1, 2004 to June 29, 2007 to compare the implied volatility derived from a stochastic volatility model to that obtained using Black-Scholes. The study found that both implied volatilities were informative, but the stochastic model did not offer any improvement over the Black-Scholes model. The authors claimed that their research was the first to use minute-by-minute transaction prices to develop the one-hour-ahead future volatility.

In another recent study from Korea, Kim and Lee (2013) used the KOSPI 200 index options data from January 2001 to December 2010 to investigate the effectiveness of arbitrage-free models developed from nonparametric smoothing methods. The results indicated that, when no-arbitrage constraints were not imposed, local volatility models were no better than the ad-hoc Black-Scholes method. When no-arbitrage constraints were considered in deriving the local volatility function from the total implied volatility surface, however, it improved the pricing performance in terms of both estimation and prediction.

Choi and Park (2014) used the KOSPI 200 index before and after the financial crisis to identify the best volatility measure between historical volatility, implied volatility, and the volatility index, in terms of forecasting power for the realized volatility. The period of study was segmented into three, namely, pre-crisis from January 2003 to July 2007, global financial crisis from August 2007 to September 2010 , and post-crisis from October 2010 to April 2012. The authors concluded that the Korean volatility index had the highest predictive power during the pre-financial-crisis period, which was enhanced when historical volatility was added. However, the implied volatility had the most predictive power for realized volatility during and after the financial crisis, that is, when the volatility was high.

Meanwhile, a study by Dixit et al. (2010) investigated the informational efficiency of implied volatility as compared to volatilities obtained with GARCH and EGARCH using the S\&P CNX Nifty index option, for a period that covered June 2001 until June 2007 (June 4 , 2001 was the starting date for the index option in the Indian securities market). The study found evidence against the hypothesis of implied volatility that subsumed all the information of future realized volatility, indicating that there was mispricing in the options contract in the Indian securities market.

A more recent study by Kumar and Jaiswal (2013) assessed the informational content provided by the implied volatility of calls and puts, calculated from the Black-Scholes option pricing model, and by model-free implied volatility, namely the volatility index in the Indian stock market. The study used the intraday pricesfor the index and the option, and the period of the study was January 1 to December 15 , 2005. Using the generalized method of moments, they obtained mixed outcomes that indicated that both measures of implied volatility (model-based and model-free) were biased. In spite of this, the implied volatility from the Black-Scholes option pricing model was efficient and contained the information in the ppmodel-free implied volatility. The results of this study supported the findings of Fleming (1998) and Becker et al. (2006), but contrasted with those of Jiang and Tian (2005).

Another contemporary study by Singh (2013) examined six models, namely the moving average historical volatility, EWMA, GARCH, EGARCH, Black-Scholes, and Nifty VIX, for their effectiveness at forecasting future volatility. The author found the Black-Scholes to be the best model for forecasting future volatility over varied moneyness-maturity dimensions of option pricing in the National Stock Exchange of India.The Nifty VIX was ranked last among the models but was found to be reliable in determining the price of the Nifty index option. The uniqueness of this study lay in its use of moneyness-maturity data from 2006 until 2011, when the Nifty reached it highest and lowest points respectively. On the other hand, an earlier study by Singh and Ahmad (2011) used one year of closing price data, from January 1 to December 31, 2008, and found no clearly superior model out of Black-Scholes, the volatility index, GARCH, GJR-GARCH, and PGARCH in terms of forecasting accuracy. However, the GARCH improved the forecasting accuracy when it was added into the forecasting process.

In another recent piece of research, Shaikh and Padhi (2013) look at the informational content of ex-ante volatility for ex-post volatility using the non-overlapping monthly India Volatility Index. Instead of using a simple OLS approach, they add the Error-in-Variable, instrumental variable technique, two-stage least squares, and quantile regression to get a more robust estimate of the future realized volatility. 
The conclusion was that the Indian VIX implied volatility contained a good amount of information about the futures market volatility and was the investors' fear gauge index for the Indian capital market.

A pioneering study on informational content in the context of Malaysia was conducted by Prima Sakti and Mohamad (2015), using data from 100 trading days between November 2013 and February 2014 for 475 warrants. He found that the implied volatility was not a good predictor for future volatility. This is in line withCanina and Figlewski (1993) findings. However, he found that the implied volatility did contain some relevant information, which provides support for Day and Lewis (1988) findings.

\subsection{CONCLUSION}

From the past literature on the informational content or predictive power of implied volatility, we found no consensus to indicate that the implied volatility has strong predictive power or contains all the information needed to forecast realized volatility. There are several points of difference in the previous research that may be responsible for the different outcomes. First is the method selected for calculating the implied volatility, such as the Black-Scholes (1973) used by Prima Sakti and Mohamad (2015), Black's (1976) approach used by Ederington and Guan (2002c), the model-free implied volatility proposed by Britten-Jones and Neuberger (2000) that was adopted by Jiang and Tian (2005), and the volatility index implied volatility (Singh, 2013). The variety of outcomes may also be due to the use of different types of options. The Black-Scholes formula used to obtain the implied volatility is based on the American type of option but in the market there are also European-style options whose characteristics are different.

From Figure 1 below we can see the forecasting models that have been used in 93 empirical papers on volatility forecasting reviewed by Poon and Granger (2003). In those papers, one or more volatility models, such as implied volatility and GARCH volatility forecasting, were pitted against one another in order to determine the best possible model for forecasting future realized volatility. The three time-series models tested were the historical volatility model, the ARCH family of volatility models and the stochastic model. In the historical volatility models the expected standard deviation $(\sigma)$ at time $t$ has to be determined from the historical returns prior to the estimation of the volatility model.

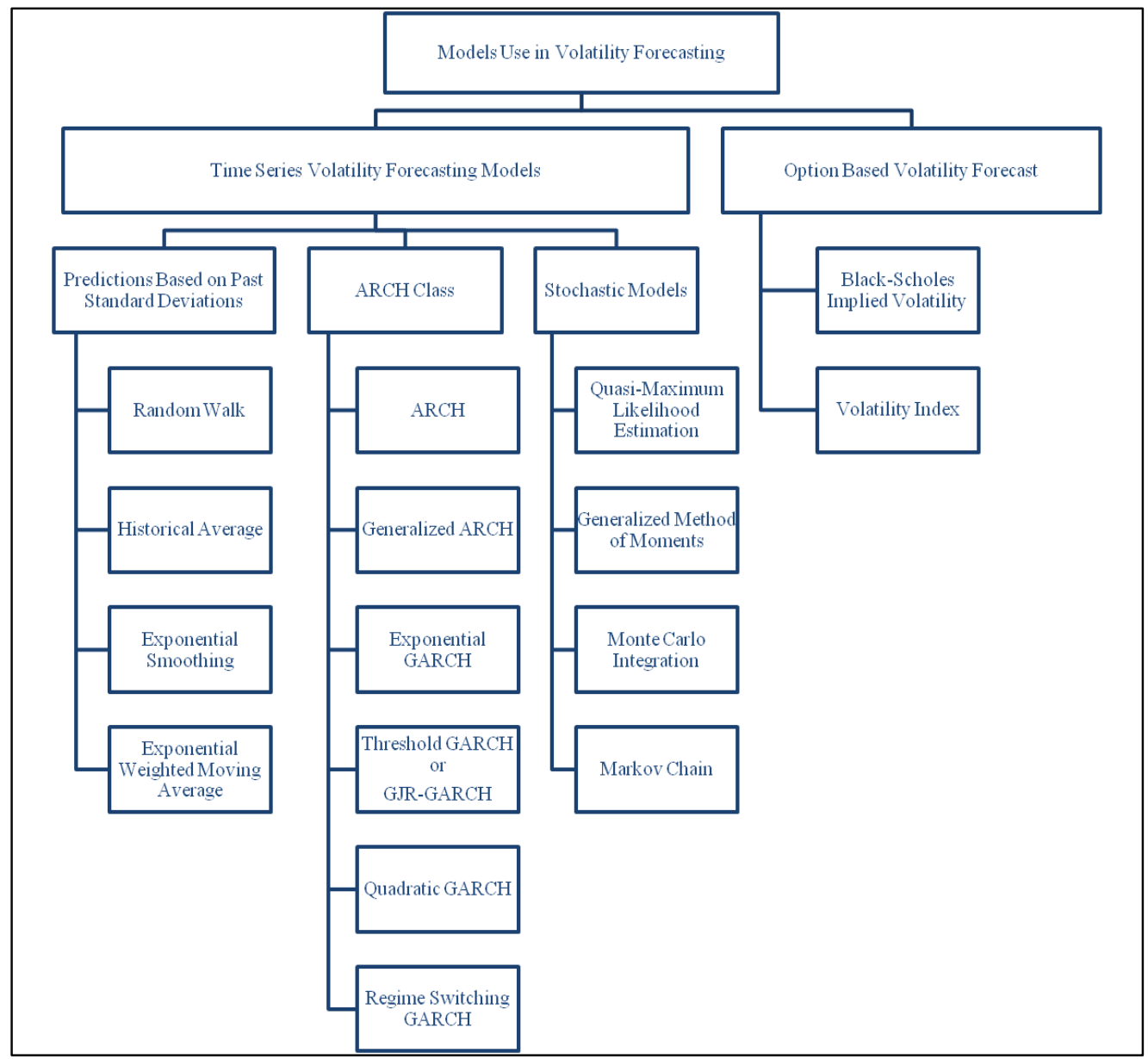

Figure 1 Past studies on volatility forecasting Sources : Poon and Granger $(2003,2005)$

The remaining two types of volatility models, the $\mathrm{ARCH}$ family and stochastic volatility models, were developed in response to the constant volatility issue of the Black-Scholes model. The ARCH family accounts for the conditional heteroscedasticity in the residual which is an important source of inefficiency. The historical volatility models use the sample standard deviations, while the ARCH model developed 
by Engle (1982) uses an autoregressive time-series approach to account for persistence in volatility estimation. A stochastic process in which the future values are conditional on the past values is assumed. The Poon and Granger (2003) survey found the GARCH model (Bollerslev, 1986) to be the most commonly used model of the ARCH family, as it can capture the serial correlation in the error term using a smaller number of parameters.

The final group of volatility models is classified as stochastic models. Here, the price of the underlying security is treated as a random variable. Permitting the price to vary in these models improves the accuracy of the calculations and forecasts. The unpredictable movement of the volatility makes the stochastic volatility model more flexible, but it also has no closed form that can be estimated directly using the maximum likelihood method.

From the 93 papers in the review, Poon and Granger (2003) shortlisted 66 that had pairwise comparisons, and ranked the volatility forecasts. A summary of their comparison is given in the figure below. Their overall ranking was lead by the option-implied volatility, followed by historical volatility and the GARCH model. However, they were unable to comment on the performance of the stochastic volatility due to the small number of studies focusing on it. In contrast, most of the studies focus on the option-implied volatility.

Futher, Poon and Granger (2003) highlighted that one of the issues when choosing the best method for forecasting volatility is which model to use. They suggested that the choice would depend on the objectives of forecasting volatility, namely whether it is for risk and risk management purposes or for option pricing. In risk management, models with tail distributions are needed, while for option pricing the option-implied volatility possesses stronger volatility forecasting power than the time-series models.

In the previous literature, the frequency of data used to produce the implied volatility varied according to data availability, from every minute (Byun et al., 2011), to daily (Shaikh and Padhi, 2013), to monthly (Christensen and Prabhala,1998). In addition, the assets studied were diverse, including those such as commodity options (Szakmary et al., 2003), stock options (Lamoureux and Lastrapes, 1993), index options (Ederington and Guan, 2005), currency options (Xu and Taylor, 1995), and exchange traded funds (Duan and Lin, 2014). The methodology used by most of the researchers on the informational content of the implied volatility is the traditional OLS. Studies by Fleming (1998) and Kumar and Jaiswal (2013) that applied the General Method of Moments found that the implied volatility was a biased forecast but did contain relevant information on future realized volatility. By and large, this survey of the literature suggests there is no consensus to indicate that the implied volatility has stronger predictive power than historical time series in forecasting realized volatility.

\section{References}

Amin, I. K., \& Ng, K.V. (1997). Inferring Future Volatility from the Information in Implied Volatility in Eurodollar Options: A New Approach. The Review of Financial Studies, 10(2), 333-367.

Andersen, T., \& Bollerslev, T. (1998). Answering the Skeptics: Yes, Standard Volatility Models Do Provide Accurate Forecast. International Economic Review, 39, $885-905$.

Bacha, O.I. (2012). Financial Derivatives : Markets and Applications in Malaysia (3rd ed.), McGraw-Hill (Malaysia) Sdn. Bhd, Shah Alam, Malaysia

Becker, R., Clements, A.E., \& White, S.I. (2006). On the Informational Efficiency of S\&P 500 Implied Volatility. North American Journal of Economics and Finance, $17,139-153$.

Beckers, S. (1981). Standard Deviations Implied In Option Prices As Predictors Of Future Stock Price Variability. Journal of Banking \& Finance, 5(3), 363-381.

Bentes, S. R. (2015). A Comparative Analysis Of The Predictive Power Of Implied Volatility Indices And GARCH Forecasted Volatility. Physica A: Statistical Mechanics and its Applications, 424, 105-112.

Birkelund, O. H., Haugom, E., Molnár, P., Opdal, M., \& Westgaard, S. (2015). A Comparison Of Implied And Realized Volatility In The Nordic Power Forward Market. Energy Economics, 48, 288-294.

Black, F. (1976). The Pricing Of Commodity Contracts. Journal Of Financial Economics, 3(1), 167-179.

Black, F., \& Scholes, M. (1973). The Pricing of Option and Corporate Liabilities. The Journal of Political Economy, 81(3), 637-654.

Bluhm, H.H., \& Yu, J. (2001). Forecasting Volatility: Evidence from German Stock Market. Working Paper, Economics Department, University of Auckland.

Bollerslev, T. (1986). Generalized Autoregressive Conditional Heterokedasticity. Journal of Economics, 31, $307-327$.

Britten-Jones, M., \& Neuberger, A. (2000). Option Prices, Implied Price Processes, and Stochastic Volatility. The Journal of Finance, 55(2), 839-866.

Busch, T., Christensen, B. J., \& Nielsen, M. Ø. (2011). The Role Of Implied Volatility In Forecasting Future Realized Volatility And Jumps In Foreign Exchange, Stock, And Bond Markets. Journal of Econometrics, 160(1), 48-57.

Canina, L., \& Figlewski, S. (1993). The Informational Content of Implied Volatility. Review of Financial Studies, 6(3), 659-681.

Chiras, D. P., \& Manaster, S. (1978). The Information Content Of Option Prices And A Test Of Market Efficiency. Journal of Financial Economics, 6(2), $213-234$.

Choi, W.C., \& Park, S.B. (2014). A Study on the Prediction of Realized Volatility of KOSPI 200 Index Option: Pre \& Post the Global Financial Crisis. International Journal of Economics and Finance, 6(12), 15-26.

Christensen, B. J., \& Hansen, C. S. (2002). New Evidence On The Implied-Realized Volatility Relation. The European Journal of Finance, 8(2), 187-205.

Christensen, B. J., \& Prabhala, N. R. (1998). The Relation Between Implied And Realized Volatility. Journal of Financial Economics, 50(2), 125-150.

Day, T.E., \& Lewis, C.M. (1988). The Behaviour of the Volatility Implicit in the Price of Stock Index Option. Journal of Financial Economics, 22 (1), 103-122.

Day, T.E., \& Lewis, C.M. (1992). Stock Market Volatility and the Information Content of Stock Index Option. Journal of Econometrics, 52(1), 267-287.

Day, T.E., \& Lewis, C.M. (1993). Forecasting Future Market Volatility. The Journal of Derivatives, 1(2), 33-50.

Dixit, A., Yadav, S.S., \& Jain, P. (2010). Informational Efficiency of Implied Volatilities of S\&P CNX Nifty Index Option: A Study in Indian Securities Market. Journal of Advances in Management Research, 7(1), 32-57.

Duan, C.-W., \& Lin, J.-C. (2014). The Predictive Power Of Volatility Models: Evidence from the ETF Market. Investment Management and Financial Innovations, $11(2), 100-110$.

Ederington, L., \& Guan, W. (2002a). Is Implied Volatility an Informationally Efficient and Effective Predictor of Future Volatility? Journal of Risk, 4, 29-46.

Ederington, L., \& Guan, W. (2002b). Measuring Implied Volatility: Is an Average Better? Which Average? Journal of Futures Market, $20,811-837$.

Ederington, L., \& Guan, W. (2002c). Why are Those Options Smiling? Journal of Derivatives, 10, 9-34.

Ederington, L., \& Guan, W. (2005). The Information Frown in Options Prices. Journal of Banking \& Finance, 29, $1429-1457$.

Engle, R.F. (1982). Autoregressive Conditional Heteroscedasticity with Estimates of the Variance of United Kingdom Inflation. Econometrica, 50(4), 987-1008.

Fama, E.F. (1965). The Behaviour of Stock Market Prices. The Journal of Business, 38(1), 34-105.

Filis, G. (2009). An Analysis between Implied Volatility and Realised Volatility in the Greek Derivative Market. Journal of Emerging Market, 8(3), 251-263.

Fleming, J. (1998). The Quality of Market Volatility Forecasts Implied By S\&P 100 Index Option Prices. Journal of Empirical Finance. 5(4), $317-345$.

Frijns, B., Tallau, C., \& Tourani-Rad, A. (2010). The Information Content of Implied Volatility: Evidence from Australia. The Journal of Future Markets, 30(2), 134155.

Glosten, L., Jagannathan, R., \& Runkle, D. (1993). On the Relation Between the Expected Value and the Volatility of the Nominal Excess Return on Stocks. Journal of Finance, 48, 1779-1801.

Guo, D. (1996). The Information Content Of Implied Stochastic Volatility From Currency Options. The Canadian Journal of Economics/Revue Canadienne d'Economique, 29, S559-S561. 
Hansen, L. P. (1982). Large Sample Properties of Generalized Method of Moments Estimators. Econometrica: Journal of the Econometric Society, 50(4), 1029-1054 Harvey, C.R., \& Whaley, R.E. (1992). Market Volatility Prediction and the Efficiency of the S\&P100 Index Option Market. Journal of Financial Economics, 31, 43-73.

Heath, D., Jarrow, R., \& Morton, A. (1992). Bond Pricing And The Term Structure Of Interest Rates: A New Methodology For Contingent Claims Valuation. Econometrica: Journal of the Econometric Society, 60(1) (Jan., 1992), 77-105.

Heston, S. L. (1993). A Closed-form Solution for Options with Stochastic Volatility with Applications to Bond and Currency Options. Review of Financial Studies, 6(2), 327-343.

Hull, J., \& White, A. (1987). The Pricing of Options on Assets with Stochastic Volatilities. The Journal of Finance, 42(2), 281-300.

Jiang, G. G., \& Tian, Y. S. (2005). The Model-Free Implied Volatility and Its Information Content. The Review of Financial Studies, $18(4), 1305-1342$.

Jing, F. C., \& Gui, B. L. (2015). Volatility Forecasting: Model-Free Implied Volatility. International Conference on Education, Management, Commerce and Society (498-501). Atlantis Press.

Joon Byun, S., Woo Rhee, D., \& Kim, S. (2011). Intraday Volatility Forecasting From Implied Volatility. International Journal of Managerial Finance, 7(1), 83-100.

Jorion, P. (1995). Predicting Volatility in the Foreign Exchange Market. The Journal of Finance, 50(2), 507-528.

Jorion, P. (1996). Risk and Turnover in the Foreign Exchange Market. in Frankel, J.A., Galli, G., and Giovannini, A. (Eds), The Microstructure of Foreign Exchange Market, University of Chicago Press, 19-40.

Kazantzis, C., \& Tessaromatis, N. (2001). Volatility in Currency Market. Managerial Finance, 27(6), 1-22.

Kim, N., \& Lee, J. (2013). No-Arbitrage Implied Volatility Functions: Empirical Evidence from KOSPI 200 Index Options. Journal of Empirical Finance, 21 , 36-53.

Koopman, S.J., Jungbacker, B., \& Hol, E. (2005). Forecasting Daily Variability of the S\&P 100 Stock Index using Historical. Realised and Implied Volatility Measurements. Journal of Empirical Finance, 12(3), 445-475.

Kumar, A. V., \& Jaiswal, S. (2013). The Information Content Of Alternate Implied Volatility Models: Case of Indian Markets. Journal of Emerging Market Finance, 12(3), 293-321.

Lamoureux, C. G., \& Lastrapes, W.D. (1993). Forecasting Stock-Return Variance: Toward and Understanding of Stochastic Implied Volatility. The Review of Financial Studies, 6(2), 293-326.

Latane, H. A., \& Rendleman, R. J. (1976). Standard Deviations Of Stock Price Ratios Implied In Option Prices. The Journal of Finance, 31(2), 369-381.

Macbeth, J. D., \& Merville, L.J. (1979). An Empirical Examination of the Black-Scholes Call Option Pricing Model. Journal of Finance, 34(5), 1173-1186.

Merton, R. C. (1973). Theory of Rational Option Pricing. The Bell Journal of Economics and Management Science, 4(1), 141-183.

Nelson, D. B. (1991). Conditional Heterocedasticity in Asset Returns: A New Approach. Econometrica, 59, 347-370.

Pilbeam, K., \& Langeland, K. N. (2015). Forecasting Exchange Rate Volatility: GARCH Models Versus Implied Volatility Forecasts. International Economics and Economic Policy, 12(1), 127-142.

Poon, S. H., \& Granger, C. W. (2003). Forecasting Volatility in Financial Markets: A Review. Journal Of Economic Literature, 41(2), 478-539.

Poon, S. H., \& Granger, C. W. (2005). Practical Issues in Forecasting Volatility. Financial Analysts Journal, 61(1), 45-56.

Poon, S. H., Blair, B., \& Taylor, S. (2001). Forecasting S\&P 100 Volatility: Using High Frequency Data And Implied Volatility. Journal of Econometrics, 105, 5-26.

Powers, E., \& Xiao, G. (2014). Mispricing of Chinese Warrants. Pacific-Basin Finance Journal, 30, 62-86.

Prima Sakti, M.R., \& Mohamad A. (2015). Implied Volatility in the Options Market: Evidence from Malaysia. Manuscript Submitted for Publication.

Schmalensee, R., \& Trippi, R. R. (1978). Common Stock Volatility Expectations Implied By Option Premia. The Journal of Finance, 33(1), 129-147.

Scott, E., \& Tucker, A. L. (1989). Predicting Currency Return Volatility. Journal of Banking \& Finance, $13(6), 839-851$.

Seo, S. W., \& Kim, J. S. (2015). The Information Content Of Option-Implied Information For Volatility Forecasting With Investor Sentiment. Journal of Banking \& Finance, 50, 106-120.

Shaikh, I., \& Padhi, P. (2013). The Information Content Of Implied Volatility Index (India VIX). Global Business Perspectives, 1(4), $359-378$.

Shaikh, I., \& Padhi, P. (2015). The Implied Volatility Index: Is 'Investor Fear Gauge'or 'Forward-Looking'?. Borsa Istanbul Review, 15(1), 44-52.

Shastri, K., \& Sirodom, K. (1995). An Empirical Test Of The BS And CSR Valuation Models For Warrants Listed In Thailand. Pacific-Basin Finance Journal, 3(4), $465-483$.

Shu, J., \& Zhang, J.E. (2003, Jan/Feb). The Relationship Between Implied and Realized Volatility of S\&P 500 Index. WILLMOTT Magazine, 83-91.

Singh, V.K. (2013). Effectiveness of Volatility Models in Option Pricing: Evidence from Recent Financial Upheavals. Journal of Advances in Management Research, $10(3), 352-375$

Singh, V.K., \& Ahmad, N. (2011). Forecasting Performance of Volatility Models for Pricing S\&P CNX Nifty Index Option via Black-Scholes Model. The IUP Journal of Applied Finance, 17(3), 53-67.

Szakmary, A., Ors, E., Kim, J. K., \& Davidson, W. N. (2003). The Predictive Power Of Implied Volatility: Evidence From 35 Futures Markets. Journal of Banking \& Finance, 27(11), 2151-2175.

Viteva, S., Veld-Merkoulova, Y.V., \& Campbell, K. (2014). The Forecasting Accuracy Of Implied Volatility From ECX Carbon Options. Energy Economics, 45, 475484.

Whaley, R.E. (2000). The Investor Fear Gauge. The Journal of Portfolio Management, 26(3), 12-17.

Wong, W. K., \& Tu, A. H. (2009). Market Imperfections And The Information Content Of Implied And Realized Volatility. Pacific-Basin Finance Journal, 17(1), 5879.

Xu, X., \& Taylor, S. J. (1995). Conditional Volatility And The Informational Efficiency Of The PHLX Currency Options Market. Journal of Banking \& Finance, 19(5), 803-821.

Zakoian, J. M. (1994). Threshold Heteroskedastic Models. Journal of Economic Dynamics and Control, 18(5), 931-955. 